more than any of your sons would have thought possible.

To the presbyopic eye, looking backward over the dim years, it seems that it must have been the people of "J.'s" type in Cambridge who have really counted in the revolution of the nineteenth century. "All the world's a stage," and a born stage-manager has, perhaps, as much to do with the success of a play as the "stars" themselves.

THE FLEUR-DE-LYS.

The Genus Iris. By W. R. Dykes. With Fortyseven Coloured Drawings by F. H. Round, One Coloured Plate of Seeds by Miss R. M. Cardew, and Thirty Line Drawings by C. W. Johnson. Pp. 245. (Cambridge University Press, I9r3.) Price 6l. 6s. net.

NO more fitting tribute could have been pre1 pared to the memory of Sir Michael Foster than a monograph of the group of plants he loved so well and studied with so deep an interest, and the volume produced by Mr. Dykes would without doubt have evoked Sir Michael's warmest approbation.

The senus Iris, like Crocus and so many other monocotyledonous genera, offers a particularly fascinating field of study from the beauty of form and colour displayed and the remarkable diversity of the species. Mr. Dykes is to be congratulated in having cultivated the majority of the species in his own garden, and with such success that the illustrations, with but one exception, have been prepared from the plants grown by him at Godalming. These illustrations, by Mr. F. H. Round, are elegant works of art which have been very faithfully reproduced in colour, and form a valuable addition to the volume. The Cambridge Press deserves a special mention in this connection, both for the beauty of the plates and for the style in which the monograph has been published.

Mr. Dykes has spared himself no pains in searching English, Continental, and American herbaria for his material, and, in particular, Kew, with its herbarium and library, proved to be a mine of wealth. He has wisely studied the type specimens with the original descriptions of all the "species" of Iris, and has thereby been able to arrive at a definite idea as to the actual number of such "species" as are really worthy of specific rank. By ignoring the records of species in local floras, unless they could be verified by actual specimens, Mr. Dykes may have left some gaps in the distribution tables of some of the species, but he has certainly avoided many possible sources of error.

$$
\text { NO. 2282, VOL. 9I] }
$$

Irises are not only plants of interest to the gardener, but they are also of interest to the plant-breeder for the facility with which they may be hybridised. In this direction the late. Sir Michael Foster was, of course, an expert, and the hybrids he produced were always a source of the keenest pleasure to him.

In addition to the ease with which hybridisation may be effected, variation is also characteristic of many species, and it is owing to this tendency that so much confusion as to the limits of species has arisen. Mr. Dykes has constant occasion to allude to this fact, for not only do the plants vary in their wild state, but they show themselves particularly prone to manifest variations under cultivation. Mr. Dykes, however, has been in no hurry to rush to conclusions, but has taken time thoroughly to digest the mass of material which he has studied, and botanists, we feel sure, will agree that they owe him a deep debt of gratitude for the sound and careful work he has done.

The early pages of the monograph are occupied by general matter dealing with the literature of the iris, structure, distribution, and cultivation, followed by outlines of the different sections of the genus. The species are then described very fully under their respective sections, with full citations of specimens and detailed setting-out of their geographical distribution, followed by useful notes on the affinities of each species.

It is not possible to attempt any criticism of this the essential part of the book, and its merits can only be adequately realised by one working over the material. It may, however, safely be said that $\mathrm{Mr}$. Dykes has produced a work with much care and sound judgment, the value of which will increase as years pass by.

\section{THE CHEMISTRY OF FATS AND ALLIEU SUBSTANCES.}

Chemie der Fette, Lipoide und Wachsarten. By Dr. W. Glikin. Erster Band: pp. xvi +789 ; Zweiter Band: pp. $\mathrm{xi}+788$. (Leipzig: Gebrüder Borntraeger, r9r3.) Price, 2 vols., 72 marks.

1 NOTABLE feature of this work is the 1 amount of consideration given to the physiological chemistry of the fats, and to the general chemistry of the lipoids. The question of the origin of fat in the animal body is of much interest and importance; and in the earlier chapters of the first volume Dr. Glikin gives an account of the experimental evidence on which arguments have been based to show that the fat of the animal body may be produced from fat 